\title{
EVIL SPEECH: A REVIEW OF JONATHAN BLUM'S LAST WORD
}

If there is, in this world, one insidious problem that the fiction writer is best equipped to explore, a bug in the human code that assures conflict, it's that we're not very good at knowing each other-at seeing into, and out from, each other's minds. How can we, sealed off in bodies and skulls with only glancing access to one another's dark, capacious interiors? We're not even very good at knowing ourselves. Much of what we do originates below consciousness, inscrutable as metabolism. Plumbing the depths requires a deliberate, ongoing study of our behavior and others' reactions to it, and tricky triangulation to potentially unflattering conclusions. Who has the courage? Who has the clarity?

Kip Langer, the hero of Jonathan Blum's taut, sleek novella Last Word (Rescue Press, 2013), is a perfect specimen of Homo obliviousis. Thirty-five years old, divorced, an orthognathic (jaw) surgeon, Kip lives with his thirteen-year-old son, Eric, his second wife, Andi, and her two young daughters in a suburban development somewhere in the southeastern U.S. The first sentence-told from Kip's point of view in what becomes, over the course of the novella, a masterful finesse of unreliable narration-seems neutral enough on first read, but is loaded with data: "If I learned computers, like my wife Andi tells me to, really learned them, I'd have more in common with the boy, I know, and all this might not have happened."

Blum writes with tremendous economy and compression. Last Word, at eighty-six pages, punches far above its weight, as does every one of its paragraphs and sentences. The word "learned" in that first sentence works hard to point up Kip's ignorance, as will the notion, soon proven woefully inadequate, that what he needs is "more in common with the boy."

Eric is an eighth grader at Traubman V. Goldfarb Day School Academy (annual tuition: $\$ 18,700$ ), where he's ostracized, most severely in Shoshanah Kalstein's Hebrew/Bible/Siddur/Israel-Interconnectedness class, for his chubbiness, his shyness, and his inability, when called on to speak, to do anything more than mumble or make "incomprehensible puffing noises from the side of his mouth." As the story gets underway and we're invited into the daily life of a highly observant family, whose people and routines Blum draws with warmth and vividness, we discern through Kip's befuddlement 
that Eric's situation at school, and the emotional damage it's inflicting, are serious. The feat of this novella is how artfully Blum winds these two narrative lines-Eric's anger and his father's failure to understand it - to rub and burn while setting into place pieces of a larger puzzle. For literary fiction, Last Word is gripping.

It's also incredibly funny. Blum satirizes a certain wealthy Jewish subculture with delicious exactitude, much of it compressed into proper namesDevi Kreuzer, Dickie Schmertz, Ripe Pecan Whole Body Fitness Complexand laser-sharp descriptions, such as that of Vashti Glick, an angry school official at a Conference of Remedial Alternatives, "springing forward in her layered celestial-colored gown of mall batik." Blum is especially good with Traubman V. Goldfarb's parents and administrators, who, in response to a rash of security breaches in the school's computer network, convene a series of meetings whose prim conscientiousness quickly degenerates into rowdy debate. These melees are hilarious and dismaying; they both pursue and neglect the community's high ideals, and reveal a toxic internal seepage of an ancient and rigorous outward defensiveness.

The novella is folded, chronologically and thematically, around the celebration of Purim. In the Book of Esther, the key text of Purim, Esther, wife of the Persian king, and Mordecai, Esther's uncle, expose a plot by Haman, one of the king's advisors, to exterminate all the Jews in the country. The king's decree can't be reversed, so he issues a new decree giving the Jews the right to "stand for their life, to destroy, to slay and to cause to perish, all the power of the people and province that would assault them." The ensuing slaughter of non-Jews and narrowly averted genocide have reflections deep at the muddy heart of Last Word, where persecution and retribution, particularly among children-particularly among children with computerscan crush souls. Computers, at Traubman V. Goldfarb, are the equivalent of guns at Columbine, and there are bullets flying everywhere. As the school's frazzled parents and administrators attempt to intervene, Blum shows how the myriad forces and counterforces of a personal conflict between father and son-the need for self-definition and control, dominance and defense, questions of fairness and responsibility and authority-travel up and down the social scale (family, neighborhood, school, community, nation), across continents and centuries, and between the real and the virtual world-a new play/battleground where adolescents, lethally skilled and largely unsupervised, inflict and suffer terrible damage. 
Blum can squeeze this entire spectrum of concerns into a short scene or bit of dialogue like the following, which deftly echoes ancient prejudices and assignations of blame while revealing current ones, and practically contains the entire novella's DNA:

"My feelings are NOT HURT!" Eric blasted, at a volume and preciseness of articulation that were unusual for him. "These people deserve whatever happens to them. If you can't see that, it's not my problem."

"Who deserves?" I demanded again. "Were girls messing with you? T.B.S.? Or was it that Westenthal from Jacksonville? Do you think he did this with girls looking on, giggling? Or are there other boys? Don't tell me Dickie or Lowell did this."

Kip's voice is masterful, and deserves a longer audition. Here is Kip in a state of temporary elation shortly after Eric has escaped indictment, if not blame, in an early round of the hacking scandal:

The following afternoon, a fifth-grade boy from a local public school was brought into my office. A classmate had knocked him unconscious the day before during gym class. He'd received three blows, producing two fracture lines on the left side of the jaw, the loss of two lower molars, and serious swelling. He was a small kid with a close-cropped haircut, not from our part of town, and though I see jaw fractures, even multiple jaw fractures, all the time, something about the expression in his eyes-absent, almost as if the eyes had no understanding of what the jaw knew perfectly-shook me up and even sickened me a little. The bullying at public school, I guess it was: things I'd seen and been through, that my father had seen and been through, that I had done everything in my power to protect my own son from. I secured the kid's jaw with titanium screws and plates, told him in six to eight weeks he would be as good as new, and clapped a five-dollar bill in his palm to go take his mom for a milkshake. I drove home counting my kids' blessings. 
The marvelous description of the brutalized boy's eyes having "no understanding of what the jaw knew perfectly" mirrors Kip's disjointed awareness - he's barely aware of how badly Eric is bullied, and in fact bullies him harder than his schoolmates do-as well as the disparity between Kip's acute powers of observation when it comes to physical appearance and his dismaying myopia when it comes to feelings. Kip never misses a chance to point out a deformity or defect, especially in his son, or to goad Eric into joining him in crude, juvenile lasciviousness. It occurs to the reader, though never to Kip, that Eric may be gay. "It occurs to the reader, though never to Kip" might be the subtitle of Last Word, which is a prècis on misunderstanding and its ally, hearsay. Traubman V. Goldfarb's parents and administrators are wary of Lashon hara, the Hebrew term for evil speech, for accusing or denigrating a person behind his or her back, yet Lashon hara is viral in the classrooms and meeting rooms and computer network, and everyone seems content to trust it as a news source. Kip learns nearly everything about Eric's behavior in school from his stepdaughters, who often haven't witnessed the behavior themselves. When Kip does try to get Eric's side of the story directly, he's too aggressive and incriminating to earn his son's confidence, and in several intense, moving scenes when Eric is brave enough to reach out for understanding, leaving himself vulnerable, Kip can't resist sticking the knife in.

How does Blum paint such a sad, tawdry picture of humankind and still allow us to laugh, albeit aghast, while looking at it? What's funny about a father who's so clueless about his own behavior and others' feelings that he causes everyone around him discomfort and pain? It's preposterous and somehow unbelievable, given our highly evolved, sophisticated sensory equipment, that we could be so oblivious. Last Word gets this, and gets that we're not as evolved as we like to think. Even when the citizens of Traubman V. Goldfarb begin to understand what's been going on, even when they achieve some clarity into one another's thoughts and feelings and needs, some of them just don't care. Some people are out for themselves. It's a testament to Blum's faith and considerable artistry that he's able to keep Kip from being one of these people, and to leave us puzzling over why we empathize with him, why we refrain from persecuting him for his deformity. The desire to connect with another human being is one we're all familiar with. If that desire is genuine, Blum seems to say, it counts for a lot, however clumsy and hurtful the execution. 